\title{
AVALIAÇÃO IN VITRO DA ATIVIDADE ANTICARIOGÊNICA DO EXTRATO DE Verbena bonariensis $L$.
}

\section{Fernanda Cristina Gontijo Evangelista ${ }^{1 *}$; Tatiane Vieira Braga ${ }^{2}$; Letícia} Márcia da Silva Tinoco³; Sarah Ferreira Guimarães"; Rosana Gonçalves

Rodrigues das Dores ${ }^{4}$; Fernando de Pilla Varotti ${ }^{1}$; Maria das Graças Carvalho²; Adriano de Paula Sabino².

\author{
${ }^{1}$ Universidade Federal de São João Del-Rei, Divinópolis/MG \\ ${ }^{2}$ Universidade Federal de Minas Gerais/MG \\ ${ }^{3}$ Universidade Federal dos Vales do Jequitinhonha e Mucuri/MG \\ ${ }^{4}$ Universidade Federal de Ouro Preto/MG \\ *e-mail:fernandacge@gmail.com
}

\section{Resumo}

A família Verbenaceae é encontrada principalmente em regiões tropicais e distribuída aproximadamente em 100 gêneros, compreendendo o gênero Verbena, com cerca de 250 espécies. Dentre essas espécies encontra-se a Verbena bonariensis L., conhecida popularmente como muçambá ou erva-ferro e empregada popularmente como um antibiótico natural. Streptococcus mutans, Streptococcus mitis e Streptococcus oralis estão envolvidos na formação de cáries dentárias. O processo envolve a aderência bacteriana, formação de biofilme e desmineralização do esmalte dentário através do ácido produzido pelos micro-organismos. $\mathrm{O}$ presente trabalho investigou a atividade anticariogênica do extrato das folhas de $V$. bonariensis L. pelo método de difusão em disco. A espécie foi coletada no campus da Universidade Federal de Ouro Preto. A identificação do material vegetal foi realizada no Herbário José Badini da UFOP e material testemunho (exsicata) depositada sob número OUPR 26753. O extrato etanólico das folhas foi preparado pelo método de maceração e seco em evaporador rotatório. A avaliação da atividade antibacteriana foi realizada pelo método de difusão em disco. O teste foi realizado em ágar Mueller-Hinton inoculado com cepas de S. mutans (ATCC 25175), S. mitis (ATCC 49456) e S. oralis (ATCC 10557), partindo da suspensão direta das colônias (escala 0,5 de McFarland). Discos de papel de filtro impregnados com 
$10 \mu \mathrm{L}$ do extrato etanólico $50 \mathrm{mg} / \mathrm{mL}$ foram avaliados em 3 repetições. Após a incubação da placa em estufa a $37^{\circ} \mathrm{C}$ por 24 horas, mensurou-se o halo de inibição ao redor dos discos. Não ocorreu formação de halo inibitório ao redor dos discos testados. $\mathrm{Na}$ avaliação da atividade antibacteriana de extratos vegetais são considerados ativos os extratos que exibem halo de inibição maior ou igual a 7,0 mm. $\mathrm{O}$ extrato de $V$. bonariensis L. não apresentou atividade anticariogênica frente às cepas testadas.

Palavras-chave: Anticariogênica; Verbena bonariensis L; bactérias.

Apoio financeiro: CNPq e FAPEMIG. 